TITLE:

Histochemical Studies on Fat Absorption in the Jejunal Mucosa after Total Pancreatectomy in Dog(Abstract_要旨 )

$\operatorname{AUTHOR}(S)$ :

Yoshizawa, Yuji

\title{
CITATION:
}

Yoshizawa, Yuji. Histochemical Studies on Fat Absorption in the Jejunal Mucosa after Total Pancreatectomy in Dog. 京都大学, 1977, 医学博士

ISSUE DATE:

1977-07-23

URL:

http://hdl.handle.net/2433/221485

RIGHT: 


\section{【146 】}

\begin{tabular}{|c|c|}
\hline 氏 & $\begin{array}{l}\text { 沢 雄 } \\
\text { 济亏 }\end{array}$ \\
\hline 学位の種類 & 学 \\
\hline 学位記番号 & 論 医 博 第 695 号 \\
\hline 学位授与の日付 & 昭 和 52 年 7 月 23 日 \\
\hline 学位授与の要件 & 学 位 規 則 第 5 条第 2 項 該 当 \\
\hline 学位論文題目 & $\begin{array}{l}\text { Histochemical Studies on Fat Absorption in the Jejunal } \\
\text { Mucosa after Total Pancreatectomy in Dog } \\
\text { (膵臟全剔犬における小腸粘膜での脂肪吸収の組織化学的研究) }\end{array}$ \\
\hline
\end{tabular}

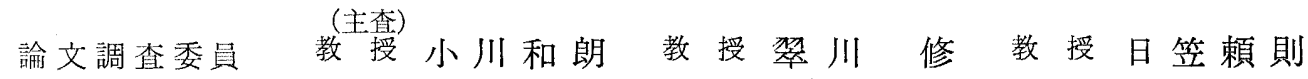

\section{論文内容 の要旨}

膵臓は, 内外両分泌機能をむっており, 膵全剔後では, 崨機能の欠落により, 糖尿病, 脂肪肝及び消 化吸収障害をまねき, 膵全剔術後管理の重要な問題点となってくる。糖尿病と脂肪肝は, 適量の insulin 投与により，かなりの障害軽減をはかることができるが, 脂肪及び蛋白質の消化吸収障害は, その根底 に膵外分泌機能廃絶があるだけに，その対策は困難をきわめる。しかし膵全剔後 insulin に estrogenを 併用するととにより, steatorrhoe の傾向は軽減し, 体重減少す insulin のみの投与に比し目立って少 ないことが報告されている。

私は, 膵全剔後の消化吸収機能を, 空腸粘膜の形態学的並びに組織化学的立場から検索し, 特に障害 の強い脂肪の消化吸収と，乙れに及ぼす estrogenの効果について検討した。その結果を要約すると次 の如くである。

\section{A. 組織学的検索}

腺管層の肥厚を認めたが, 空腸粘膜絨毛の萎縮, 平坦化及び消失等, 粘膜吸収面積の減少を示す所見 は，認められなかった。

B. 脂肪の吸収

1）絶食時における変化

正常犬（非手術犬）を24時間絶食させると, 粘膜上皮, 固有層, 中心乳び腔及び筋板のいずれに歹殆 んど脂肪滴を認めない。しかるに, 膵全剔 insulin 単独投与犬では, 24時間絶食後といえども, 粘膜上 皮に若干の脂肪滴を認め, 時には中心乳び腔にあ見られたが, estrogen 併用犬では, これらの脂肪榈 は，正常犬絶食時と同様消失していた。

2) オリーブ油投与時における変化

正常犬では, オリーブ油投与後約30分で, すでに䋐毛の尖端部に近い粘膜上皮の核上部に脂肪滴が現 われ, 投与後約 3 時間では, 粘膜固有層, 中心乳び腔, 筋板及び粘膜下リンパ叢に多数の脂肪球が集積 
しており，乙の頃がオリーブ油吸収のもっとも盛えな時期と考えられる。しかし膵全剔 insulin 単独投 与犬では， 3 時間後においても全く吸収像は，認められなかった。また estrogen 併用犬においても同 様であった。

3) 中鎖脂肪投与時に抢ける変化

正常犬では，オリーブ油同様，投与後約 30 分で絨毛尖端上皮細胞より吸収されるが，すでに90分後に 著明な吸収像が認められ，オリーブ油に比し明らかに吸収が速く，その吸収過程において，組織化学的 に脂肪が中心乳び腔に出現することはなく，粘膜内脂肪の消失は，オリーブ油に比し極めて速やかであ った。insulin 単独投与犬では, 中鎖脂肪投与後 3 時間で 䋐毛尖端より僅かながら吸収されているのが 認められた。しかし, estrogen の影響は認めなかった。

4) オレイン酸投与時に抢ける変化

正常犬では，投与後約 30 分ですでに吸収が開始され, 約 2 時間後には粘膜固有層, 中心乳び腔, 筋板 に多数の脂肪球を認め，乙の頃が收収のもっとも盛んな時期と考えられる。しかし，insulin 単独投与 犬では， 2 時間後においても，脂肪の吸収は全く認められなかった。しかるに， estrogenを併用すると， 投与後 2 時間では，粘膜上皮，固有層及び中心乳び腔に多数の脂肪球が出現し，また燐脂質染色により これらの脂肪球は, 上く染色された。

C. 空腸粘膜醭素活性の変化

膵全剔 insulin 単独投与犬では, alkaline phosphatase, adenosine triphosphatase 及び succinic dehydrogenase 活性の著明な低下を認めた。estrogon の併用により，これらの酵素活性はいずれあよ く維持され，正常犬における活性と差を認めなかった。

尚，acid phosphatase 及び esterase 活性は，膵全剔による影響を認めなかった。

\section{論交審査の結果の要旨}

膵全剔後の脂肪, 蛋白質の消化吸収障碍は，その根底に膵外分泌機能の廃絶があるだけに，その対策 は極めて困難である。斯る点から，本研究においては，膵全剔後インシュリンとエストロゼンを投与す ると，脂肪便をみる回数が減少し，同時に体重減少がインシュリンの单独投与時よりも目立って少なく なるという臨床的钼察所見から必ずや脂肪の吸收が改善されるようになるものと荐元，そのよって来た る所以を実験に匡した。

その結果, 膵全剔後インシュリンのみを投与したものにあっては, 空腸粘膜の alkaline phosphatase, adenosine triphosphatase 及び succinic dehydrogenase 活性の著明な低下が組織化学的に立証されるが， エストロゼンをも併用したものでは，それらの活性低下がよく防止せられ，健常時のそれと何等変ると ころはなく，腸粘膜からのオレイン酸の吸収もそれが併用投与によって著るしく改善され得るに至る事 実を明らかならしぬ得たのである。以上，本研究は膆全剔後の脂肪の消化吸収能をエストロゼンの投与 が改善する機作についての解明在行ったもので，膵全剔後の術後管理の改善に寄与するところ極めて大 である。

よって，本諭文は医学博士の学位論文として価値あるものと認める。 